症例

$$
\begin{aligned}
& \text { 人工血管パイパス術後に発生した末梢血管狭窄に対する } \\
& \text { バルーンアンギオプラスティーの経験 } \\
& \text { 広島大学第 } 1 \text { 外科（主任：松浦雄一郎教授） } \\
& \text { 林載 鳳金広啓一未田泰二郎 } \\
& \text { 浜 中 喜晴石原浩 }
\end{aligned}
$$

血管錐子に起因する血行障害の報告は極めて少ない，著者らは血行再建術に際し使用 したブルドック鎮子が原因と考えられる動脈狭窄の1例を経験したので報告する.

症例は70歳の女性で，右下肢痛を訴えて来院. 諸検查にて閉塞性動脈硬化症による浅 大腿動脈完全閉塞と診断し, 大腿㮏窩動脈バイパス術を施行した。術後の造影にてグラ フト吻合直下, 即ちブルドック鋁子をかけたと思われる部に狭窄を認めた。血管内視鏡 に上る基礎的観察所見々考光合わせ，血管鉗子に起因する狭窄々診断した。 その治療に 当り, 人工血管切開部からバルーンを挿入してフンギオプラスティーを行い良好な結果 が得られた．血管銝子といえどもその使用に当っては細心の注意が必要と考えられた。 また人工血管からの血管内視鏡及びバルーンフンギオプラスティーは, 吻合部狭窄に対 しても応用可能な診断及び治療手技であると考えられる.

索引用語：血管鉗子, 血管内視鏡, バルーンフンギオプラスティー

\section{緒 言}

医原性動脈血栓症の報告は時にみられるが，血管鉗 子に起因する血行障害の報告は見当たらない．著者ら は最近ブルドック䤞子が原因と考えられる動脈狭窄症 例を経験したのでここに報告する。

\section{症例}

患者：70歳，女性.

主訴：右下肢痛。

家族歴：特記すべきことなし。

既往歴：昭和52年, 下壁心筋梗塞.

現病歴：昭和62年10月頃より右下肢の冷感，しびれ 感が出現した。同年11月には間歇性跛行，安静時痛む 出現してきたので近医受診，血管病变を疑われ当科を 紹介された。

入院時現症：血王130/80mmHg，胸部，腹部には特 記すべき病変は認めない，大退動脈は左右とも良好に 触知できるが，膝窩動脈，足背動脈，後怪骨動脈は左 右とも触知できなかった．冷感，チアノーゼは認めな かった。

入院時検査所見：血液生化学的検查にて特別な異常

1988年 7 月 20 日受付 1988 年12月 21 日採用
は認めなかった。心電図にて II, III, aVFに異常 Q 波 を認めた。

下肢血管造影(図 1)：総大腿動脈は良好に開存して いたが，図左に示すょうに右浅大眼動脈はその基部で 完全閉塞していた，因右に示すよらに右膝䈑動脈は良 好な造影所見が得られた。

冠動脈造影：右冠動脈の\#3に $99 \%$, 左前下行枝に diffuse narrowing, 左回施枝の\#13に75\%の狭窄を認 めた.

以上の所見から下壁梗塞を伴ら，右浅大腿動脈の閉 塞性動脈硬化症と診断し, 自覚症状も重篤であること より人工血管による血行再建術を施行することとし た。

第 1 回手術所見及び術後経過：径 $8 \mathrm{~mm}$ のリング付 expanded poly-tetrafluoro ethylene $人 工$ 血管 (IMPRA ${ }^{\circledR}$ ) を用いて総大腿動脈一膝窩動脈バイパス 術を施行した。この際, 型通りに中权部及び末梢部を ブルドック鉗子にて血行遮断して吻合操作を行った。 術後も右足関節周囲の軽い疼痛か残っていた。術後 3 週目に血管造影を行ったところ図 2 に示すよらに，人 工血管は開存していたがその末梢に95\%狭窄を認め た。図 3 に狭窄部の術前後の造影を並置する，㹟窄部 


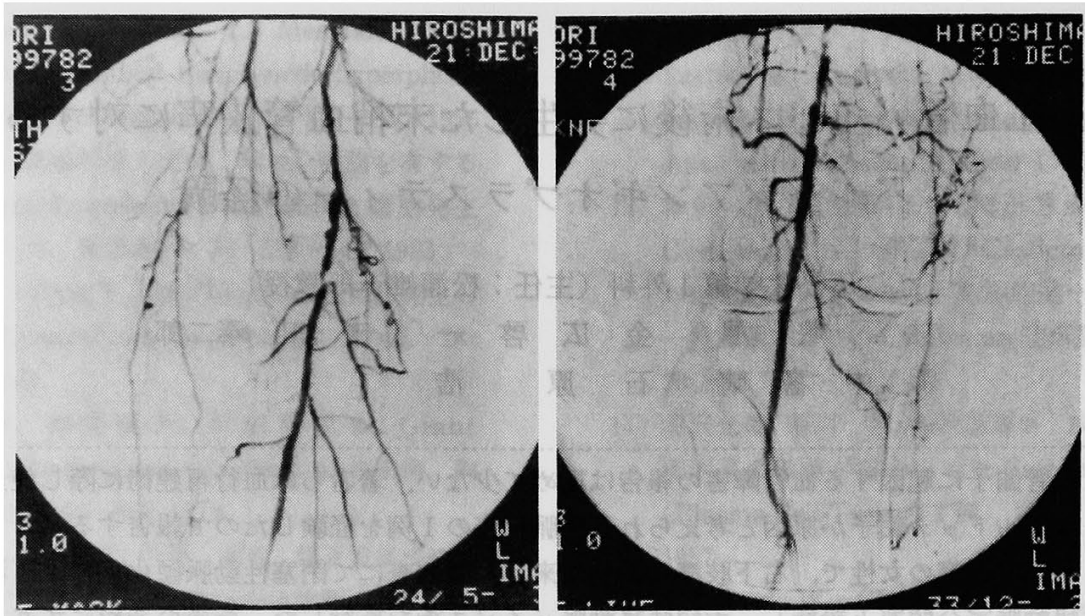

図 1 術前下肢血管造影：右浅大駺動脈の完全閉塞が認められる.

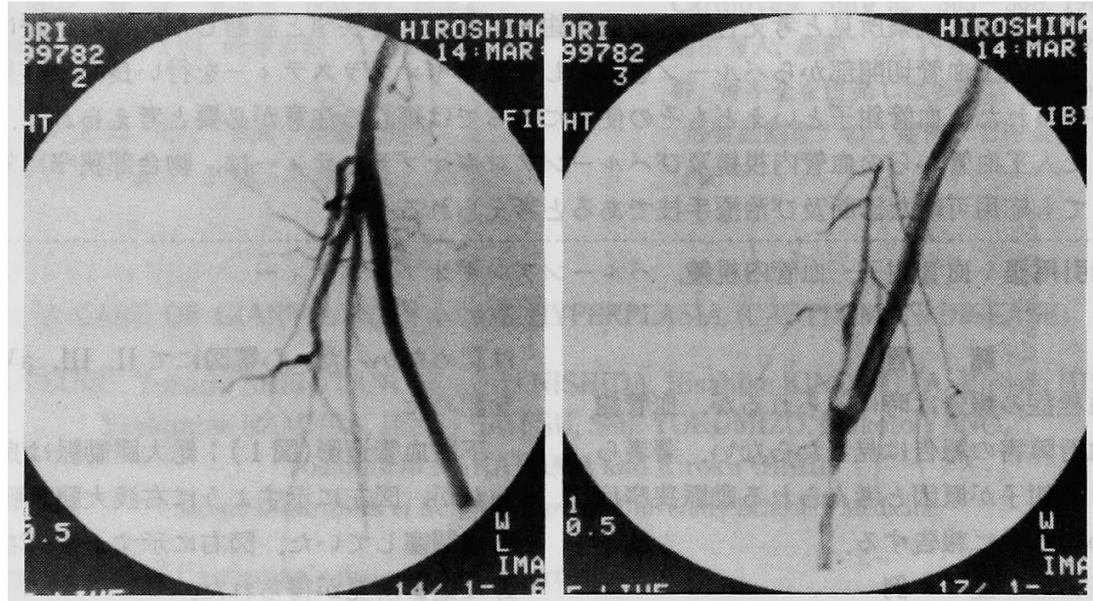

図 2 術後下肢血管造影：人工血管の開存は良好であるが,その末梢に狭窄を認める。
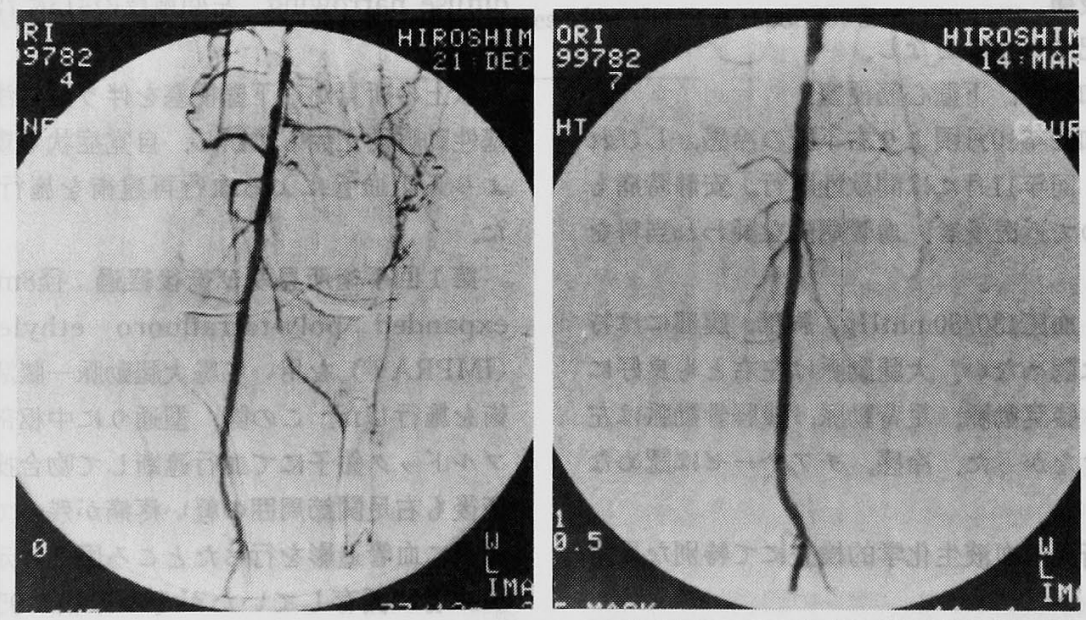

図 3 左が術前, 右が術後 
に該当する場所は，術前一見きれいに造影されている ように見えるがその両側には虫喰い状陰影がみられ， 同部にも動脈硬化性病変は及んでいたと考えられる. 後で述べる上らに動脈硬化病変と血管鎮子に上る内皮 損傷があいまって狭窄が形成されたすのと考え再手術 を計画した。

第 2 回手術所見及び術後経過 : 局所麻酔下に大腿中 央部で $3 \mathrm{~cm}$ の皮切を加えて人工血管を露出した，末梢 血管吻合部より約 $15 \mathrm{~cm}$ はなれた人工血管に小切開を 加光，逆流防止弁付き7F シースを捙入し，それを経由 して血管内視鏡にて吻合部を観察した．図４に示すよ らに吻合部に血栓等の形成はみられなかった。次いで 径 $4 \mathrm{~mm}$, 長さ $4 \mathrm{~cm}$ のバルーンカテーテルを人工血管か ら择入し，手圧にて 1 分問ハルーンを拡張させ，その 後にウロキナーゼを 6 万単位動注した。図 5 に示す上 $5 に 95 \%$ 狭窄は $20 \%$ 狭窄にまで改善した，外来にて ワーファリン, チクロピシン投与下に経過観察中であ

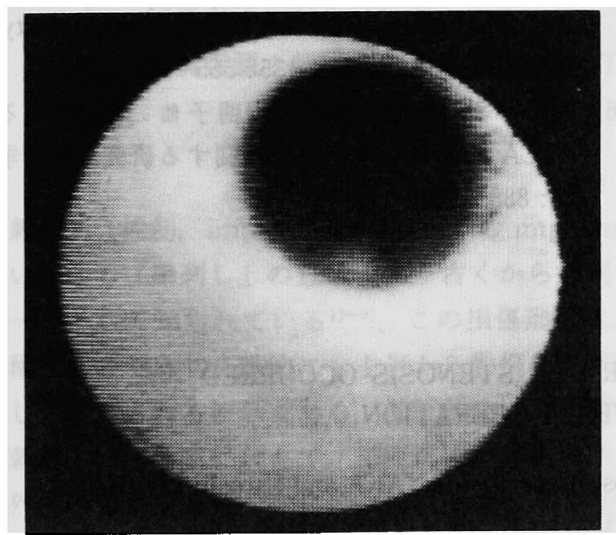

图 4 血管内視鏡像：白く見える部分は人工血管の内 壁で黑い円状の部分が末梢側血管との吻合部であ る、吻合部狭乍は否定される。
るが，症状の再発はなく良好な経過をたどっている。 考 察

本論文において報告した症例は，浅大眼動脈閉塞症 に対する血行再建術に際し，末梢自己血管の血管鉗子 をかけた部に一致して術後狭窄を来たしたすのであ る.

これまで基礎的研究により，動脈硬化と血栓は互い に深い関わりを持つことが知られている．即ち，血小 板血栓の形成は動脈硬化の原因となり"逆に動脈硬化 巣は血栓形成の局所因子として働くとされている2． ただし通常内皮の障害がなければ血栓は形成されにく いことす知られている゙๋.そこで著者らは，実験的に犬 の血管に血管鉗子をかけ，内腔から血管内視鏡にて観 察を行ったところ，図6に示すように明暸な臣迫痕が 認められ内皮の損傷が推察された。また観察開始30分 後には同部に一致して血栓の形成も観察された。

以上のような知見より，本症例では動脈硬化血管を ベースに，血管鉗子による内皮損傷で血栓が形成され 狭害が進行したものと考えた。

動脈硬化及び内皮障害に関俰して，血流の速い部分 にできる血栓は，主として血小板とフィブリンより成 る白色血栓であり,一方, 静脈系に血流らっ滞を原因 としてできる血栓は，主として赤血球とフィブリンよ り成る赤色血栓である4 . 我々の症例の場合は, その成 因から考えて典型的な白色血栓と考えられた，白色血 栓は赤色血栓に比しプラスミノゲンが少ないことと， ウロキナーゼが到達しにくいことより, 血栓溶解療法 の効果は弱いとされている．また発症後数時間以内で あれば血栓溶解療法の良い適応であるが，本症では発 症後 3 週間たっており，血拴㾂解の効果は望めず，： ルーンフンギオプラスティーの適応であろうと考え た.

バルーンにても血管内皮が損傷されることが知られて
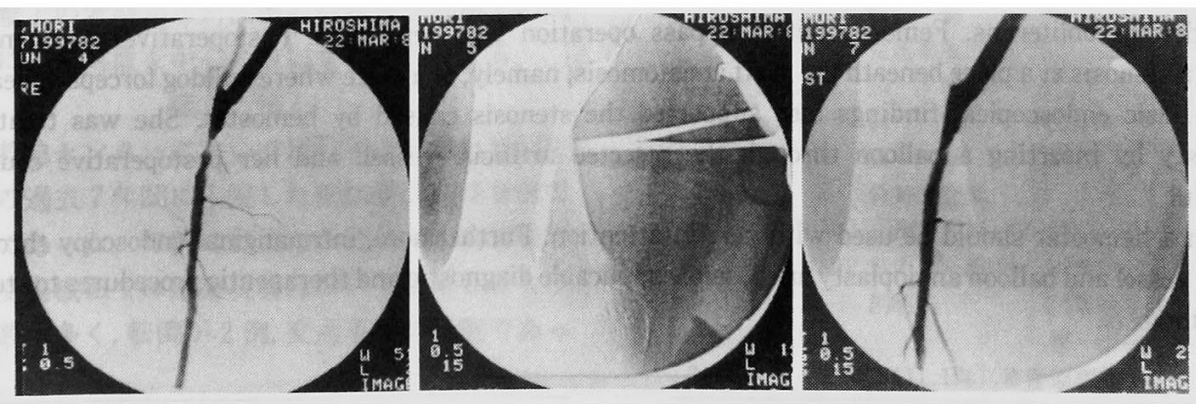

図 5 パルーンアンキォプラスティー：95\%狭窄は $20 \%$ 狭窄にまで改善した。 


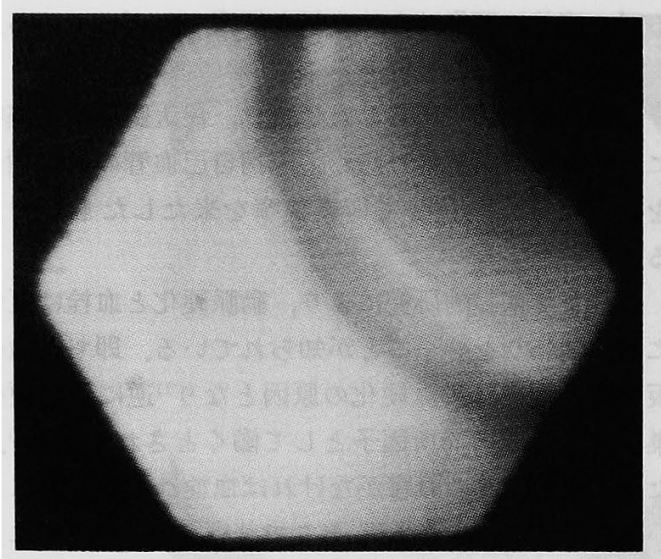

図 6 生迫痕：犬の血管に鉗子をかけ，その内腔を血 管内視鏡にて観察した。

扣り5)，それらに起因する再狭窄の発生は大きな問題 点であるが，血小板凝集抑制剤は再狭窄を減少させる といら報告すありの゙，著者らもリーファリン及びチク ロビジンを使用した。

バルーンアンギオプラスティーを施行するに当り， 著者らは残存血管走行部の深さと動脈硬化病変に伴う 径の狭小さを考慮して，人工血管からの血管内視鏡々 バルーンの㨀入を行った. 本症例のよ5に人工血管か らアンギオプラスティーを施行したという報告は只今
のところ見当たらないが，時にみられる人工血管吻合 部狭窄に対し，本法は極めて有用な診断法及び治療法 であると思われたので報告した。

$$
\text { 結語 }
$$

血管鉗子に起因すると考えられる動脈狭窄の 1 例を 報告した. その治療として人工血管経由のバルーンフ ンギオプラスティーを施行し良好な結果が得られた。

$$
\text { 文献 }
$$

1) Russell R: The pathogenesis of atherosclerosis-An update. N Engl J Med 314 : 488-500, 1986

2）田中建蔵：血栓症の症理, 日臨 44:1019-1027, 1986

3）住吉昭信：血栓症の病理, 脈管学 $14: 559-562$, 1974

4) Onoyama K, Tanaka K: Fibrinolytic activity of the arterial wall. Thromb Diath Haemorrh 21 : $1-11,1969$

5) Zuniga CWR, Formanek $A$, Tadavarthy $M$, et al: The mechanism of balloon angioplasty. Diagnostic Radiology 135 : 565-571, 1980

6）阿部博幸, 永見和久，竹本明子他：薬剤による PTCA 再狭窄の防止効果に関する研究, 脈管学 $27: 888,1987$

\title{
A CASE OF BALLOON ANGIOPLASTY FOR THE STENOSIS OCCURRED AFTER FEMOROPOLITEAL BYPASS OPERATION
}

\author{
Saihou HAYASHI, Keiichi KANEHIRO, Taijiro SUEDA, Yoshiharu HAMANAKA and Hiroshi ISHIHARA \\ The First Department of Surgery, Hiroshima University School of Medicine
}

We experienced a rare case of arterial stenosis caused by bulldog forceps used in femoropopliteal bypass operation.

A 70-year-old female visited our department complaining of pain in the right lower extremity. Various examinations indicated that she was suffered from complete obstruction of the superficial femoral artery due to arteriosclerosis obliterans. Femoropopliteal bypass operation was performed. Postoperative roentgenography revealed a stenosis at a place beneath the graft anastomosis, namely, at a place where bulldog forceps appeard to be applied. Basic endoscopical findings also supported the stenosis caused by hemostat. She was treated with angioplasty by inserting a balloon through the resected artificial vessel, and her postoperative course was uneventful.

Even a hemostat should be used with careful attention. Furthermore, intra-anginal endoscopy through the artificial vessel and balloon angioplasty are possible applicable diagnostic and therapeutic procedures to stenosis at the anastomosis. 